\title{
Short-term low-protein diet during pregnancy alters islet area and protein content of phosphatidylinositol 3-kinase pathway in rats
}

\author{
CRISTIANA S.B. SALVATIERRA ${ }^{1}$, SÍLVIA R.L. REIS ${ }^{2}$, ANA F.M. PESSOA ${ }^{1}$, \\ LETÍCIA M.I. DE SOUZA ${ }^{2}$, LUIZ F. STOPPIGLIA ${ }^{3}$, ROBERTO V. VELOSO ${ }^{2}$, \\ MARISE A.B. REIS ${ }^{2}$, EVERARDO M. CARNEIRO ${ }^{4}$, ANTONIO C. BOSCHERO ${ }^{4}$, \\ EDSON M. COLODEL ${ }^{5}$, VANESSA C. ARANTES ${ }^{2}$ and MÁRCIA Q. LATORRACA ${ }^{2}$ \\ ${ }^{1}$ Universidade Federal de Mato Grosso, Faculdade de Nutrição, Laboratório de Avaliação \\ Biológica de Alimentos, Av. Fernando Correa da Costa, 2367, 78060-900 Cuiabá, MT, Brasil \\ ${ }^{2}$ Universidade Federal de Mato Grosso, Faculdade de Nutrição, Departamento de Alimentos e \\ Nutrição, Av. Fernando Correa da Costa, 2367, 78060-900 Cuiabá, MT, Brasil \\ ${ }^{3}$ Universidade Federal de Mato Grosso, Instituto de Educação, Departamento de Psicologia, \\ Av. Fernando Correa da Costa, 2367, 78060-900 Cuiabá, MT, Brasil \\ ${ }^{4}$ Universidade Estadual de Campinas, Instituto de Biologia, Biologia Celular e Fisiologia e \\ Biofísica, Departamento de Anatomia, Av. Bertrand Russel, s/n, 13083-865 Campinas, SP, Brasil \\ ${ }^{5}$ Universidade Federal de Mato Grosso, Faculdade de Agronomia e Medicina Veterinária, Departamento de \\ Clínica Médica Veterinária, Av. Fernando Correa da Costa, 2367, 78060-900 Cuiabá, MT, Brasil
}

Manuscript received on June 11, 2014; accepted for publication on December 15, 2014

\begin{abstract}
The phosphatidylinositol 3-kinase and mitogen-activated protein kinase pathways mediate $\beta$ cell growth, proliferation, survival and death. We investigated whether protein restriction during pregnancy alters islet morphometry or the expression and phosphorylation of several proteins involved in the phosphatidylinositol 3-kinase and mitogen-activated protein kinase pathways. As controls, adult pregnant and non-pregnant rats were fed a normal-protein diet (17\%). Pregnant and non-pregnant rats in the experimental groups were fed a low-protein diet (6\%) for 15 days. Low protein diet during pregnancy increased serum prolactin level, reduced serum corticosterone concentration and the expression of both protein kinase B/AKT1 (AKT1) and p70 ribosomal protein S6 kinase ( $70^{\mathrm{S} 6 \mathrm{~K}}$ ), as well as the islets area, but did not alter the insulin content of pancreatic islets. Pregnancy increased the expression of the Src homology/collagen (SHC) protein and the extracellular signal-regulated kinases 1/2 (ERK1/2) independent of diet. ERK1/2 phosphorylation (pERK1/2) was similar in islets from pregnant and non-pregnant rats fed a low-protein diet, and was higher in islets from pregnant rats than in islets from non-pregnant rats fed a normal-protein diet. Thus, a short-term, low-protein diet during pregnancy was sufficient to reduce the levels of proteins in the phosphatidylinositol 3-kinase pathway and affect islet morphometry.
\end{abstract}

Key words: MAP kinase pathway, pancreatic islets, PI3K pathway, pregnancy, protein restriction, rats.

Correspondence to: Márcia Queiroz Latorraca

E-mail: mqlator@terra.com.br 


\section{INTRODUCTION}

Although pancreatic islet mass is relatively constant under normal conditions, it has a remarkable ability to adapt to metabolic changes. An example is pregnancy, when islet mass can increase markedly due to both $\beta$-cell hyperplasia and hypertrophy (Sorenson and Brelje 1997). An increase in $\beta$-cell proliferation is first observed around day 10 of pregnancy, peaks around day 14 and then returns to control levels by the end of pregnancy at approximately 21 days (Parsons et al. 1992). Another example of the adaptation of pancreatic islets occurs upon malnutrition, which is associated with important structural changes in the endocrine pancreas. Protein deficiency leads to reduced $\beta$-cell mass due to a decrease in the proliferation rate and an increase in apoptosis (Swenne et al. 1992, Petrik et al. 1999). Additionally, when the data are corrected for age and weight, a reduction in $\beta$-cell size and total islet volume, a lower proportion of $\beta$-cells per islet, a degranulation of $\beta$-cells and $\beta$-cells with a preponderance of abnormal pale granules have been observed (Heard and Stewart 1971, Pimstone 1976, Weinkove et al. 1977).

Nutrients such as amino acids and glucose and certain growth factors such as insulin-like growth factor 1 (IGF-1), glucocorticoids, and the somatolactogenic hormones placental lactogen $(\mathrm{PL})$, prolactin $(\mathrm{PRL})$ and growth hormone $(\mathrm{GH})$ increase pancreatic $\beta$-cell mitogenesis (Parsons et al. 1992, Swenne et al. 1992, Scharfmann and Czernichow 1996, Hogg et al. 1993, Hugl et al. 1998, Brelje et al. 1993, Rafacho et al. 2007). 17ß-estradiol (E2) does not increase $\beta$-cell proliferation but does enhance the biosynthesis of insulin and is involved in $\beta$-cell survival (Nadal et al. 2009). Progesterone (P) appears to have a role in decreasing $\beta$-cell mass (Picard et al. 2002).

In growing rats receiving a low-protein diet, serum corticosterone concentrations are increased, the plasma concentration of IGF-1 and the number of GH and PRL receptors (GH-R and PRL-R) are reduced, at least in the liver(Herbert and Carrillo 1982, Prewitt et al. 1982, Maes et al. 1984). In rodents, the PL, PRL, E2 and P levels increase during the second half of pregnancy (Nadal et al. 2009), and elevated concentrations of corticosterone are observed during the later stages of pregnancy (Dupouy et al. 1975). Increases in the mRNA expression of GH-R and PRL-R (Moldrup et al. 1993) and the expression of PRL-R in the pancreas (Brelje and Sorenson 1997) have also been observed during pregnancy. Dexamethasone, a synthetic glucocorticoid, reverses the PRL-induced upregulation of islet mass by inhibiting cell proliferation and increasing apoptosis (Weinhaus et al. 2000).

PRL exerts its biological effects mainly by activating the Janus kinase 2/signal transducer and activator of transcription 5 (JAK2/STAT5) pathway (Ihle et al. 1998, Galsgaard et al. 1999, Levy and Darnell 2002). PRL can also stimulate insulin receptor substrate (IRS) 1/2, phosphatidylinositol 3-kinase (PI3K) and mitogen-activated protein kinase (MAPK) in rat $\mathrm{Nb} 2$ node lymphoma cells, in COS cells, in JAK2-deficient cell lines (Rao et al. 1995, Yamauchi et al. 1998) and in cultured neonatal rat islets (Amaral et al. 2003). Moreover, PRL enhances the expression of several genes related to growth and differentiation but reduces the expression of genes involved in apoptosis in pancreatic islets from adult female rats (Bordin et al. 2004). PL acts by binding to PRL-R and triggering the activation of downstream signaling pathways, including the JAK2/STAT5, PI3K/protein kinase B/AKT (AKT), extracellular signal-regulated kinase 1/2 (ERK1/2), adenylate cyclase/cyclic adenosine monophosphate (AC/cAMP) and intracellular calcium pathways (Amaral et al. 2003, 2004, Brelje et al. 2002). IGF-1 stimulates $\beta$-cell proliferation mainly via tyrosine autophosphorylation and activation of the IGF-1-receptor tyrosine kinase, which results in the downstream tyrosine phosphorylation of IRS2 and the subsequent activation of PI3K, AKT and the $70 \mathrm{kD}$ S6 kinase (p70 ${ }^{\mathrm{S} 6 \mathrm{k}}$ ) (Hugl et al. 1998, 
Dickson et al. 2001). In contrast, the effects of GH are initiated via activation of the JAK2/STAT5 pathway (Cousin et al. 1999, Gahr et al. 2002). Crosstalk can occur at different levels between the PRL-R, GH-R, IGF-1-R and insulin-receptor (IR) signal transduction pathways (Hugl et al. 1998, Amaral et al. 2003, Cousin et al. 1999).

Changes in the protein expression and/or activation/phosphorylation of a protein common to these pathways could result in alterations in proliferation and apoptosis. These two events could be associated with the expansion and reduction of pancreatic islet mass that are observed during pregnancy with a low-protein diet. Thus, we investigated the effects of short-term protein restriction during pregnancy on the morphometry and the expression and phosphorylation of several proteins involved in the PI3K and MAPK pathways in pancreatic islets. Studies that evaluate the role of protein restriction on molecular and cellular determinants involved in $\beta$-cell adaptation during pregnancy are particularly important to identify possible causal factors of gestational diabetes and could contribute towards its prevention.

\section{MATERIALS AND METHODS}

\section{ANIMALS AND DiET}

The animal experiments were approved by the Institutional Ethics Committee in Animal Experimentation (Universidade Federal de Mato Grosso). Virgin female Wistar rats (90 days of age) were obtained from the University's breeding colony. Mating was achieved by housing males with females overnight, and pregnancy was confirmed by the examination of vaginal smears for the presence of sperm. Pregnant and non-pregnant females were each randomly assigned to two diet groups: control and lowprotein. The control nonpregnant (CNP) and pregnant (CP) groups were fed a $17 \%$ protein diet, and the low-protein nonpregnant (LPNP) and pregnant (LPP) groups were fed a $6 \%$ protein diet from days 1 to 15 of pregnancy. The diets were isocaloric, as previously described (Filiputti et al. 2008). During the experimental period, rats had free access to food and water and were housed at $22^{\circ} \mathrm{C}$ with a $12 \mathrm{~h}$ light:dark cycle. At the end of this experimental period, the rats were weighed and killed by decapitation. Blood samples were collected and allowed to clot; sera were stored at $-20^{\circ} \mathrm{C}$ for the subsequent measurement of $17 \beta$-estradiol and progesterone by EIA (BioChem ImmunoSystems, Italy), prolactin by EIA (ALPCO Diagnostics, USA) and corticosterone by an enzyme-linked immunosorbent assay (Assay Design, USA). Serum albumin levels (Doumas et al. 1971) were determined immediately after decapitation. Since it was not possible to evaluate all variables in the same animals, the number of individual experiments varied among groups.

\section{MORPHOMETRY AND IMMUNOHISTOCHEMISTRY}

For morphological analyses, the pancreases of rats were kept for approximately $8 \mathrm{~h}$ in $10 \%$ buffered formalin and then processed by routine methods for histological analysis. After histological sectioning (5- $\mu \mathrm{m}$-thick sections) and mounting onto positivized slides (ImmunoSlide-EasyPath ${ }^{\circledR}$ ), the anti-insulin immunohistochemistry technique was performed. The sections were de-waxed in xylene and rehydrated in decreasing concentrations of alcohol (in distilled water). The blocking of endogenous peroxidase was performed by incubating the slides in a $3 \%$ solution of hydrogen peroxide in distilled water for $15 \mathrm{~min}$ at room temperature. For antigen retrieval, the samples were microwaved for $2 \mathrm{~min}$ in a citrate buffer of $\mathrm{pH}$ 6.0. Non-specific binding was minimized with a $15 \mathrm{~min}$ incubation in 5\% skimmed milk (Molico ${ }^{\circledR}$ ) diluted in distilled water. The sections were covered with a solution containing the guinea pig anti-swine insulin polyclonal antibody (A0564 - Dako, Corp., Carpinteria, CA, dilution 1:150) and were incubated in a moist chamber at $37^{\circ} \mathrm{C}$ for $60 \mathrm{~min}$. The samples 
were then washed in distilled water and treated with an anti-IgG guinea pig biotinylated secondary antibody (61-4620, ZYMED, Invitrogen USA) for $30 \mathrm{~min}$ in a moist chamber at room temperature. Next, the sections were washed in distilled water and treated with a streptavidin-peroxidase conjugate (DAKO Corp., Carpinteria, CA) for $30 \mathrm{~min}$ in a moist chamber at room temperature. Staining was subsequently visualized with the application of red chromogen (VECTOR ${ }^{\circledR}$ NovaRED) for $5 \mathrm{~min}$. The sections were then washed in distilled water and counterstained with Harris hematoxylin for $30 \mathrm{~s}$. Next, the samples were washed in water for 1-2 min, dehydrated in increasing concentrations of alcohol, cleared in xylene and mounted with Entellan (Merck, Darmstadt, Germany Sigma Chemical Co., Saint Louis, USA). Approximately 20 islets were observed in one field of view for each slide. The slides were evaluated by light microscopy, and images were captured with a digital camera (Sony Cyber-shot DSC-H5) and measured using the Motic ${ }^{\circledR}$ Images Plus 2.0 ML software. In the morphometric technique the observer was blinded as to the groups and the pancreatic tissue was assessed for the area of the islets.

\section{WESTERN BLOTTING}

After isolation by collagenase digestion of the pancreas and subsequent separation by handpicking, groups of islets were pelleted by centrifugation $(15,000 \times \mathrm{x})$ and then resuspended in $50-100 \mu \mathrm{L}$ of a buffer containing protease and phosphatase inhibitors (Amaral et al. 2003, Kelley et al. 1994). The islets were sonicated, and the total protein content was determined (Bradford 1976). Samples containing $50 \mu \mathrm{g}$ of protein from each experimental group were incubated for $5 \mathrm{~min}$ at $80^{\circ} \mathrm{C}$ with a $4 \mathrm{X}$ concentrated Laemmli sample buffer (1 mmol sodium phosphate/L, pH 7.8; 0.1\% bromophenol blue; $50 \%$ glycerol; $10 \%$ SDS; $2 \%$ mercaptoethanol) $(4: 1, \mathrm{v}: \mathrm{v})$ and then run on $12 \%$ (ERK1, ERK2 and pERK1/2) or 10\% (AKT, pAKT, and SHC) polyacrylamide gels at $120 \mathrm{~V}$ for $90 \mathrm{~min}$. The electrotransfer of proteins to nitrocellulose membranes (Bio-Rad) was performed for $2 \mathrm{~h}$ at $120 \mathrm{~V}$ in a buffer lacking methanol and SDS. After checking the transfer efficiency by Ponceau $\mathrm{S}$ staining, the membranes were blocked with $5 \%$ skimmed milk in Tween-Tris-buffered saline (TTBS) (10 mmol Tris/L; $150 \mathrm{mmol} \mathrm{NaCl} / \mathrm{L}$; $0.5 \%$ Tween 20) overnight at $4^{\circ} \mathrm{C}$. AKT, pAKT, SHC, ERK1, ERK2 and pERK1/2, were detected on the membranes after a $2 \mathrm{~h}$ incubation at room temperature with the primary antibodies: anti-AKT1 (mouse polyclonal sc5298), anti-phospho[Ser $\left.{ }^{473}\right]$ AKT (rabbit polyclonal, sc7985), anti-SHC (rabbit polyclonal, sc288), anti-ERK1 (rabbit polyclonal, sc94), or anti-ERK2 antibodies (rabbit polyclonal, sc 154) from Santa Cruz Biotechnology, Inc. (Santa Cruz, CA, USA) or an anti-ERK1/2 (p44/42 MAPK mouse monoclonal, E10) antibody from Biolabs Inc (Beverly, MA, USA), diluted 1:500, v/v, in TTBS containing 3\% albumin (Sigma). The membranes were then incubated with a secondary specific $\operatorname{IgG}$ antibody, diluted 1:5000, v/v, in TTBS containing 3\% albumin (Sigma) for $2 \mathrm{~h}$ at room temperature. After incubation with horseradish peroxidase-conjugated secondary antibody, enhanced chemiluminescence (SuperSignal West Pico) was used to detection, by autoradiography. Band intensities were documented by digital scanning followed by quantification using the Scion Image analysis software. The numerical values obtained are expressed in arbitrary units.

To detect IR $\beta$, IRS1, IRS2, PI3Kp85, p70 ${ }^{\text {S6K }}$ and phospho $\mathrm{p} 70^{\mathrm{S} 6 \mathrm{~K}}$, samples containing $60 \mu \mathrm{g}$ of total protein were incubated with $10 \mu 1$ of the antiIR $\beta$ (rabbit polyclonal, sc 711), anti-IRS1 (rabbit polyclonal, sc 559), anti-IRS2 (goat polyclonal, sc 1556), anti-p $70^{\mathrm{S} 6 \mathrm{~K}}$ (rabbit polyclonal, sc 8418 ), or anti-phospho p70 ${ }^{\mathrm{S} 6 \mathrm{~K}}$ (mouse monoclonal, sc 8416) antibodies from Santa Cruz Biotechnology, Inc. (Santa Cruz, CA, USA) or an anti-PI3K-p85 (rabbit polyclonal 06-195) antibody from UBI (Lake Placid, NY, USA) at $4^{\circ} \mathrm{C}$ overnight. The immune 
complexes were then precipitated with protein A-Sepharose $6 \mathrm{MB}$ for $2 \mathrm{~h}$. The pellets were washed three times in a buffer containing $100 \mathrm{mM}$ Tris, 2 $\mathrm{mM}$ sodium vanadate, $1 \mathrm{mM}$ EDTA and $0.5 \%$ Triton $\mathrm{X}-100$, resuspended in $18 \mu \mathrm{l}$ of Laemmli sample buffer and boiled for $5 \mathrm{~min}$ prior to loading onto polyacrylamide gels ( $8 \%$ for IRS $1 / 2$ and $10 \%$ for IR $\beta$, PI3Kp85, p70 $0^{\mathrm{S} 6 \mathrm{~K}}$ and phospho $\mathrm{p} 70^{\mathrm{S} 6 \mathrm{~K}}$ ). Following electrophoresis, the proteins were transferred to nitrocellulosemembranes for $2 \mathrm{~h}$ at $120 \mathrm{~V}$. Non-specific protein binding to nitrocellulose was reduced by preincubating the filters in blocking buffer (5\% BSA, 10 $\mathrm{mM}$ Tris, $150 \mathrm{mM} \mathrm{NaCl}$, and $0.02 \%$ Tween 20) for $2 \mathrm{~h}$ at $22^{\circ} \mathrm{C}$. IR $\beta$, IRS1, IRS2, PI3Kp85, p70 ${ }^{\mathrm{S} 6 \mathrm{~K}}$ and phospho $\mathrm{p} 70^{\mathrm{S} 6 \mathrm{~K}}$ were detected in the nitrocellulose membranes after $2 \mathrm{~h}$ incubation at room temperature with primary antibodies (diluted 1:500, v/v, in TTBS containing 3\% albumin). The membranes were then incubated with a secondary specific IgG antibody, diluted 1:5000, v/v, in TTBS containing 3\% albumin (Sigma) for $2 \mathrm{~h}$ at room temperature. After incubation with horseradish peroxidase-conjugated secondary antibody, enhanced chemiluminescence (SuperSignal West Pico) was used for detection by autoradiography. Band intensities were documented by digital scanning followed by quantification using the Scion Image analysis software. The numerical values obtained are expressed in arbitrary units.

\section{STATISTICAL ANALYSES}

The results are expressed as the means \pm SDs for the number of rats $(n)$ indicated. For islets, $n$ refers to the number of experiments performed. Levene's test for the homogeneity of variances was used initially to check the fit of the data to parametric ANOVA assumptions. When necessary, the data were log-transformed to correct for variance in heterogeneity or non-normality (Sokal and Rohlf 1995). Data were analyzed by a two-way ANOVA test (nutritional status and physiological status). When necessary, these analyses were followed by LSD's honestly significant difference test to determine the significance of individual differences. The level of significance was set at $P<0.05$. The data were analyzed using the Statistic Software package (Statsoft).

\section{RESULTS}

Regardless of nutritional status, pregnant rats had higher weight gain and, consequently, higher final body weights $\left(\mathrm{F}_{1,83}=236.3, P<0.0001\right.$ and $\mathrm{F}_{1,83}=67.7, P<0.0001$, respectively). Additionally, enhanced serum $\mathrm{P}\left(\mathrm{F}_{1,22}=85.8, P<0.0001\right)$ and E2 $\left(\mathrm{F}_{1,23}=102.4, P<0.0001\right)$ levels were observed in pregnant rats compared with non-pregnant rats. Serum prolactin concentrations were higher in LPP than in LPNP, CP or CNP $(P<0.001)$ rats. In contrast, serum corticosterone levels were lower in LPP rats than in CP, LPNP or CNP rats. Serum albumin concentrations did not differ among groups (Table I).

Detection of IR- $\beta$, IRS-1, IRS-2 and PI3K-p85 obtained through immunoprecipitation showed no significant differences in the levels of all four proteins observed among the groups (Fig. 1A to 1D). As shown in Figure 1E, the protein levels of AKT1 were 1.5-fold higher in islets from the LPNP group compared with the CNP group. The pancreatic islets from LPP rats had lower levels of AKT1 than did the pancreatic islets from LPNP rats. No significant difference was detected in the level of AKT1 expression between $\mathrm{CP}$ and CNP rats. The phospho ${ }^{[\mathrm{Se} 473]} \mathrm{AKT} 1$ level (Fig. 1F) and the ratio of phospho ${ }^{[\mathrm{Se} 473]} \mathrm{AKT}$ 1/AKT1 (Fig. 1G) were lower in islets from low protein rats (LPP and LPNP) than in those of the control rats (CNP and $\mathrm{CP})\left(\mathrm{F}_{1,8}=25.9, P<0.001, \mathrm{~F}_{1,8}=6.4, P<0.05\right.$, respectively). In contrast, the variables were 1.3and 1.7-fold higher in the islets from pregnant rats (LPP and CP) compared with non-pregnant rats, respectively, (LPNP and CNP) $\left(\mathrm{F}_{1,8}=10.24\right.$, $P<0.02, \mathrm{~F}_{1,8}=7.7, P<0.05$, respectively). Levels of $\mathrm{p} 70^{\mathrm{S} 6 \mathrm{~K}}$ (Fig. 1H) and phosphor p70 $0^{\mathrm{S} 6 \mathrm{~K}}$ (Fig. 1I) were detected from Western blot signals from immunoprecipitated samples. As depicted in 
TABLE I

Body weight gain, final body weight, and serum albumin, 17ß-estradiol, progesterone, prolactin and corticosterone levels in pregnant and non-pregnant rats maintained on control (CNP and CP) or low-protein diets (LPNP and LPP).

\begin{tabular}{lcccc}
\hline \multirow{2}{*}{ Variable } & \multicolumn{4}{c}{ Groups } \\
\cline { 2 - 5 } & CNP & CP & LPNP & LPP \\
\hline Body weight gain $(\mathrm{g})$ & $35 \pm 16$ & $78 \pm 13^{\#}$ & $29 \pm 12$ & $79 \pm 15^{\#}$ \\
& $(17)$ & $(22)$ & $(20)$ & $(28)$ \\
Final body weight $(\mathrm{g})$ & $258 \pm 23$ & $309 \pm 24^{\#}$ & $270 \pm 18$ & $306 \pm 29^{\#}$ \\
& $(17)$ & $(22)$ & $(20)$ & $(28)$ \\
Serum albumin $(\mathrm{g} / \mathrm{dl})$ & $4.4 \pm 0.7$ & $3.9 \pm 0.4$ & $4.3 \pm 0.4$ & $4.3 \pm 0.8$ \\
& $(6)$ & $(7)$ & $(10)$ & $(6)$ \\
Serum 17ß-estradiol $(\mathrm{pmol} / \mathrm{L})$ & $89 \pm 15$ & $198 \pm 48^{\#}$ & $81 \pm 18$ & $206 \pm 44^{\#}$ \\
& $(6)$ & $(7)$ & $(6)$ & $(8)$ \\
Serum progesterone $(\mathrm{nmol} / \mathrm{L})$ & $51 \pm 22$ & $232 \pm 35^{\#}$ & $54 \pm 19$ & $188 \pm 60^{\#}$ \\
& $(5)$ & $(7)$ & $(5)$ & $(9)$ \\
Serum prolactin $(\mathrm{ng} / \mathrm{ml})$ & $5.5 \pm 1.1^{\mathrm{b}}$ & $4.0 \pm 0.6^{\mathrm{b}}$ & $5.6 \pm 1.3^{\mathrm{b}}$ & $12.6 \pm 6.6^{\mathrm{a}}$ \\
& $(3)$ & $(4)$ & $(4)$ & $(3)$ \\
Serum corticosterone $(\mu \mathrm{g} / \mathrm{dl})$ & $15.8 \pm 1.1^{\mathrm{a}}$ & $14.9 \pm 0.6^{\mathrm{a}}$ & $15.3 \pm 0.3^{\mathrm{a}}$ & $10.8 \pm 1.1^{\mathrm{b}}$ \\
& $(7)$ & $(6)$ & $(5)$ & $(4)$ \\
\hline
\end{tabular}

Values represent the means \pm SDs for the number of rats shown in parentheses. "Indicates differences in relation to non-pregnant rats (Two-way ANOVA, $P<0.05$ ). ${ }^{\mathrm{a}, \mathrm{b}}$ Mean values with unlike superscript letters were significantly different (LSD test; $P<0.05$ ).

Figure $1 \mathrm{H}$, the pancreatic islets from LPP rats expressed lower levels of $\mathrm{p} 70^{\mathrm{S} 6 \mathrm{~K}}$ than did those from LPNP rats, whereas the islets from CP rats expressed higher levels of $\mathrm{p} 70^{\mathrm{S} 6 \mathrm{~K}}$ than did those from CNP rats. The phosphor $\mathrm{p} 70^{\mathrm{S} 6 \mathrm{~K}}$ levels were 1.4-fold higher in the islets from pregnant rats (LPP and CP) in relation to non-pregnant rats (LNP and $\mathrm{CNP})\left(\mathrm{F}_{1,8}=5.32\right.$, $P<0.05$ ) (Fig. 1I). No significant differences were detected in the phosphop $70^{\mathrm{S} 6 \mathrm{~K}} / \mathrm{p} 70^{\mathrm{S} 6 \mathrm{~K}}$ ratio among groups (Fig. 1J).

As shown in Figure 2A, the expression of SHC increased 1.5-fold in the islets from rats fed a lowprotein diet in relation to rats fed the control diet $\left(\mathrm{F}_{1,8}=16.25, P<0.01\right)$. Similar results were observed in the islets from pregnant rats in relation to those from non-pregnant rats $\left(\mathrm{F}_{1,8}=15.63, P<0.01\right)$. The protein levels of both ERK1 (Fig. 2B) and ERK2 (Fig. 2C) were decreased in the islets from rats fed a low-protein diet $\left(\mathrm{F}_{1,10}=11.64, P<0.01\right.$ and $\mathrm{F}_{1,8}=$ 11.97, $P<0.01$, respectively) compared with those from rats maintained on the control diet. However, the expression of ERK1 and ERK2 was 1.4-fold $\left(\mathrm{F}_{1,10}=10.18, P<0.01\right)$ and 1.3 -fold $\left(\mathrm{F}_{1,8}=7.91\right.$, $P<0.05)$ higher in the islets from pregnant rats compared with non-pregnant rats, respectively. The phosphoERK1/2 levels were similar in islets from the LPNP, LPP and CP groups and were significantly higher in relation to those from the CNP group (Fig. 2D).

The insulin content in the pancreatic islets did not differ among groups $(\mathrm{CNP}=26 \pm 8 \mathrm{ng} /$ islet, $\mathrm{n}=4$; $\mathrm{CP}=28 \pm 8 \mathrm{ng} /$ islet, $\mathrm{n}=4 ; \mathrm{LNP}=34 \pm 8 \mathrm{ng} /$ islet, $\mathrm{n}=3$; $\mathrm{LP}=44 \pm 18 \mathrm{ng} /$ islet, $\mathrm{n}=4$ ).

The islet area in LPP rats was lower in relation to that in LPNP rats, whereas the islet area in CP rats was similar to that in CNP rats. No significant differences were observed among the islet areas in LPNP, CNP and CP rats $\left(\mathrm{CNP}=1869 \pm 2615 \mu \mathrm{m}^{2}\right.$, $\mathrm{n}=91 ; \mathrm{CP}=2613 \pm 4360 \mu m^{2}, \mathrm{n}=137 ; \mathrm{LPNP}=2585$ $\pm 3892 \mu m^{2}, \mathrm{n}=138 ; \mathrm{LPP}=1502 \pm 2000 \mu \mathrm{m}^{2}, \mathrm{n}=91$ ). 

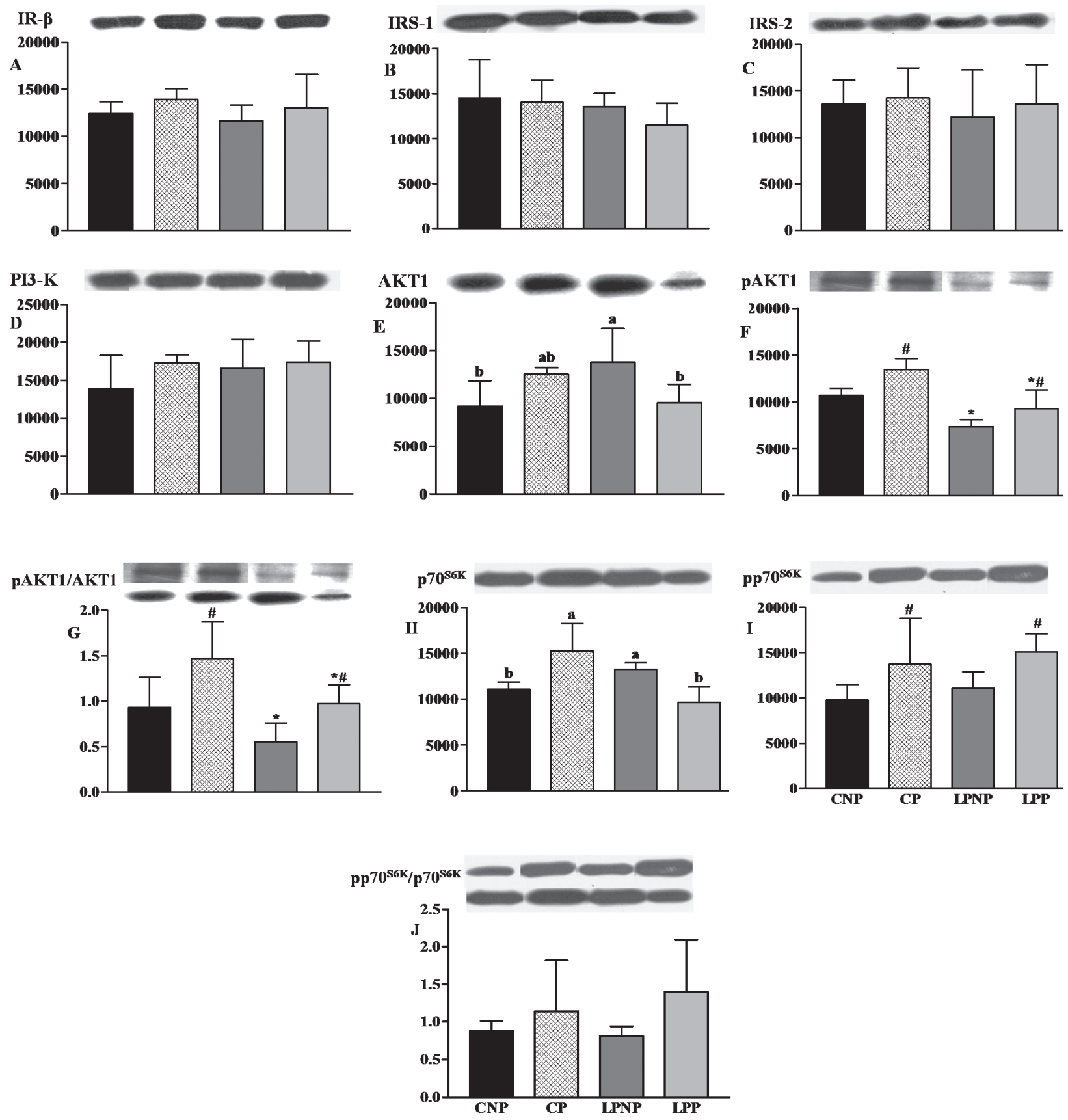

Figure 1 - Protein expression of IR- $\beta$ (A), IRS-1 (B), IRS-2 (C), the p85 subunit of PI3K (D) and AKT1 (E), phospho- ${ }^{[S e 473]}$ AKT1 levels (F), phospho- ${ }^{[\mathrm{Se} 473]} \mathrm{AKT1} / \mathrm{AKT} 1$ ratios $(\mathrm{G})$, the protein expression of $\mathrm{p} 70^{\mathrm{S} 6 \mathrm{~K}}(\mathrm{H})$, phospho-p $70^{\mathrm{S} 6 \mathrm{~K}}$ levels $(\mathrm{I})$ and phospho-p $70^{\mathrm{S} 6 \mathrm{~K}} / \mathrm{p} 70^{\mathrm{S} 6 \mathrm{~K}}$ ratios $(\mathrm{J})$ in the islets of CNP, CP, LPNP and LPP rats. Equal amounts of protein $(60 \mu \mathrm{g})$ were subjected to immunoprecipitation using antibodies anti-IR $\beta$, anti-IRS1, anti-IRS2, anti-PI3K-p85, anti-p70 ${ }^{\mathrm{S} 6 \mathrm{~K}}$, or anti-phospho p70 ${ }^{\mathrm{S} 6}$. Immunoprecipitates were analyzed by SDS-PAGE followed by immunoblotting with antibodies to IR- $\beta$, IRS-1 IRS-2, PI3K-p85, $\mathrm{p} 70^{\mathrm{S} 6 \mathrm{~K}}$ and phospho-p $70^{\mathrm{S} 6 \mathrm{~K}}$. Equal amounts of protein $(50 \mu \mathrm{g})$ were run on SDS-PAGE and blotted with anti-AKT1 and antiphospho- ${ }^{[\mathrm{Se} 473]} \mathrm{AKT} 1$. The columns represent the means \pm SDs of 3-6 independent experiments. "Indicates difference in relation to non-pregnant rats (Two-way ANOVA, $P<0.05$ ). *Indicates differences in relation to rats maintained on a control diet (Two-way ANOVA, $P<0.05)$. ${ }^{\text {a,b }}$ Mean values with unlike superscript letters were significantly different (LSD test; $P<0.05$ ). 

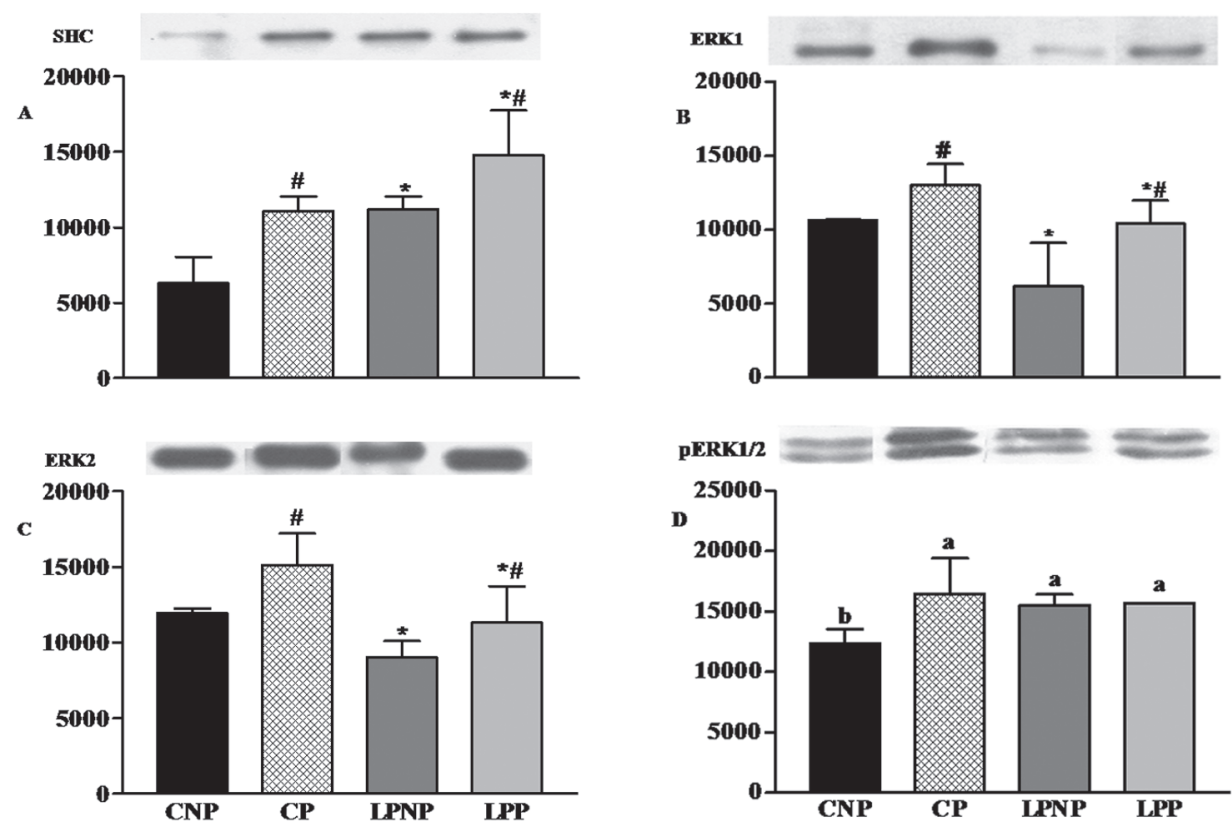

Figure 2 - The levels of the SHC (A), ERK1 (B) and ERK2 proteins (C) and phospho-ERK1/2 levels (D) in the islets of CNP, CP, LPNP and LPP rats. Equal amounts of protein $(50 \mu \mathrm{g})$ were run on SDS-PAGE and blotted with anti- SHC, anti- ERK1, anti-ERK2 and anti-phospho-ERK1/2. The columns represent the means \pm SDs of 3-4 independent experiments. "Indicates differences in relation to non-pregnant rats (Two-way ANOVA, $P<0.05$ ). *Indicates differences in relation to rats maintained on a control diet (Two-way ANOVA, $P<0.05$ ). ${ }^{\mathrm{a}, \mathrm{b}}$ Mean values with unlike superscript letters were significantly different (LSD test; $P<0.05$ ).

\section{DISCUSSION}

After the short period of low-protein diet consumption (15 d) used here, the classical alterations observed in malnourished animals (weight loss and hypoalbuminemia) were not yet present. We verified an increase in E2 and P in both $\mathrm{CP}$ and LPP rats, which is normally observed during pregnancy (Nadal et al. 2009). In disagreement with the observation that the maternal plasma total and free corticosterone concentrations in rats are increased by protein restriction and pregnancy at 15 days (Dupouy et al. 1975, Martin et al. 1977, Herbert and Carrillo 1982), in the present study, the serum corticosterone levels did not increase in $\mathrm{CP}$ rats and were decreased in LPP rats. Interestingly, the unexpected decrease in the serum corticosterone levels in LPP rats was accompanied by an early increase in the serum prolactin concentration. This increase is commonly observed in the later stages of pregnancy (Nadal et al. 2009) and suggests an inhibitory role for corticosterone in prolactin secretion (Nishino et al. 1992). Corticosterone and prolactin are involved in the structural adaptations of pancreatic islets to pregnancy.

Some studies have attempted to identify the molecular mechanisms underlying these adaptations in response to pregnancy and protein deprivation. Long-term exposure to a low-protein diet during the growth phase produces an increase in IR, IRS2 and PI3K levels and a reduction in IRS1 and $\mathrm{p} 70^{\mathrm{S} 6 \mathrm{~K}}$ expression (Araujo et al. 2004, Filiputti et al. 2008). In this study, a short-term, low-protein diet did not alter the IR, IRS1, IRS2 or PI3K-p85 levels but did increase the expression of AKT1 and $\mathrm{p} 70^{\mathrm{S} 6 \mathrm{~K}}$ in the pancreatic islets of non-pregnant rats. Pregnancy associated with protein deprivation was 
accompanied by the reduced expression of AKT1 and $\mathrm{p} 70^{\mathrm{S} 6 \mathrm{~K}}$, whereas normal pregnancy did result in an increase in the expression of $\mathrm{p} 70^{\mathrm{S} 6 \mathrm{~K}}$, but did not alter AKT1 expression. Although similar in CNP and $\mathrm{CP}$ groups, the AKT1 expression tended to increase in CP rats compared with CNP rats. Neither condition resulted in changes in the expression of IR, IRS1/2 or PI3K-p85. Interestingly, normal pregnancy does not affect the protein levels of IRS1 and IRS2; however, it increases IRS1/2 phosphorylation and its association with p85, and also increases AKT1, $\mathrm{p} 70^{\mathrm{S} 6 \mathrm{~K}}$ expression and phosphorylation in pancreatic islets (Amaral et al. 2004).

Several studies indicate that the structure and function of pancreatic islets are influenced by alterations in the expression and/or activity of IR, IRS-1, IRS-2, AKT1 and $\mathrm{p} 70^{\mathrm{S} 6 \mathrm{~K}}$. A reduced IR content in $\beta$-cells strongly impairs insulin secretion in response to glucose (Kulkarni et al. 1999). In contrast, IRS-1 deficiency produces hyperinsulinemia and increases of the $\beta$-cell mass, and the absence of IRS-2 produces hyperinsulinemia followed by islet hypoplasia and early diabetes (Kulkarni et al. 1999, Withers et al. 1998). It has been demonstrated that AKT promotes protein synthesis by modulating mTOR and its downstream target, $\mathrm{p} 70^{\mathrm{S} 6 \mathrm{~K}}$ (Hannan et al. 2003). Increased AKT1 activity is accompanied by a marked increase in $\beta$-cell mass due to enhanced cell survival and increased cell size (Tuttle et al. 2001). Additionally, $\mathrm{p} 70^{\mathrm{S} 6 \mathrm{~K}}$ deficiency produces hypoinsulinemia, islet insensitivity to glucose, a low insulin content and reduced $\beta$-cell size (Pende et al. 2000). In the present study, changes in the AKT1 and $\mathrm{p} 70^{\mathrm{S} 6 \mathrm{~K}}$ levels were not followed by alterations in the insulin content of islets. However, changes in the levels of these two proteins were accompanied by a decrease in islet area in the LPP group. Because the LPP group had lower AKT1 and pAKT1 contents and a lower $\mathrm{pAKT1}{ }^{\mathrm{Ser} 473 / \mathrm{AKT} 1}$ ratio, which are indirect indicatives of AKT1 activity, it is possible that the reduction in islet area resulted from elevated apoptosis and/or reduced AKT1-mediated cellular proliferation and growth. Corroborating with the hypothesis of elevated apoptosis, we observed that islets from LPP group exhibited elevated levels of caspase 3 and caspase 9 (unpublished data).

In several signaling pathways, the expression and phosphorylation of members of the MAPK cascade activate several transcriptional regulators to control cellular growth. Although ERK1/2 modulate insulin secretion (Longuet et al. 2005), the most important role of these proteins in pancreatic $\beta$-cells is the regulation of proliferation, cell growth, and survival (Lawrence et al. 2008). In the present study, pregnancy increased the expression of SHC and ERK1/2 independent of diet and enhanced the level of pERK1/2 only in the islets of normal pregnant rats, as previously shown (Bordin et al. 2004, Amaral et al. 2004). A low-protein diet also elevated the levels of SHC and pERK1/2 and reduced the expression of ERK1 and ERK2. Pregnancy did not increase the pERK1/2 levels in the islets of rats exposed to a low-protein diet.

In pancreatic $\beta$-cells, nutrients, hormones and growth factors modulate the expression of proteins in the SHC/ERK and IRS/PI3K/ AKT/ $\mathrm{p} 70^{\mathrm{S} 6 \mathrm{~K}}$ pathways. Prolactin has been considered an important growth factor. Prolactin is involved in the increase in islet mass and increased sensitivity to glucose that occur during pregnancy. Mechanistically, it activates proteins that are downstream of PI3K and MAPK cascades (Amaral et al. 2004). Dexamethasone, a synthetic glucocorticoid, increases the $\mathrm{p} 70^{\mathrm{S} 6 \mathrm{~K}}$ expression and pAKT1 level in pancreatic islets (Rafacho et al. 2007). Curiously, in this study, LPP rats that exhibited an increase in serum prolactin levels and a decrease in serum corticosterone concentrations also had lower $\mathrm{p} 70^{\mathrm{S} 6 \mathrm{~K}}$ and AKT1 levels. These results corroborate the observation that glucocorticoids strongly synergize with prolactin-induced STAT5 activation through distinct mechanisms involving the glucocorticoid receptor (Stocklin et al. 1996, Lechner et al. 1997, Wyszomierski et al. 1999). 
Our results show that short-term exposure to a low-protein diet during pregnancy reduces pancreatic islet area that could be related to deficiencies in the AKT1 and $\mathrm{p} 70^{\mathrm{S} 6 \mathrm{~K}}$ levels. We suggest that reduced circulating corticosterone levels altered the PI3K pathway and, consequently, cellular proliferation, growth, survival and death.

\section{ACKNOWLEDGMENTS}

This work was partly supported by the Fundação de Amparo à Pesquisa do Estado de Mato Grosso (FAPEMAT, grant number: 0786/2006) and Conselho Nacional de Desenvolvimento Científico e Tecnológico (CNPq, grant number: 305155/2004$0)$. Celso Roberto Afonso provided technical assistance for the study. This work is part of a dissertation that was presented by Cristiana dos Santos Barbosa Salvatierra as a partial requirement for her Master's degree in Health Sciences at the School of Medical Sciences, UFMT.

\section{RESUMO}

As vias da fosfatidilinositol-3-cinase e da proteína cinase ativada por mitógeno medeiam crescimento, proliferação, sobrevivência e morte das células $\beta$. Investigamos se a restrição proteica durante a prenhez altera a morfometria da ilhota ou a expressão e a fosforilação de diversas proteínas envolvidas nas vias da fosfatidilinositol-3-cinase e da proteína cinase ativada por mitógeno. Como controles, ratas adultas não prenhes e prenhes foram alimentadas com uma dieta norpoproteica (17\%). As ratas não prenhes e prenhes dos grupos experimentais foram alimentadas com dieta hipoproteica $(6 \%)$ por 15 dias. A dieta hipoproteica durante a prenhez aumentou as concentrações séricas de prolactina, reduziu as concentrações séricas de corticosterona e a expressão da proteína cinase B/ AKT1 (AKT1) e da proteína p70 ribossomal S6 cinase $\left(\mathrm{p} 70^{\mathrm{S} 6 \mathrm{~K}}\right)$, bem como a área das ilhotas, mas não alterou o conteúdo de insulina nas ilhotas pancreáticas. A prenhez aumentou a expressão da proteína homóloga ao colágeno com domínio SH2 (SHC) e a proteína cinase regulada por sinal extracelular 1/2 (ERK1/2), independente da dieta consumida. A fosforilação da ERK1/2 (pERK1/2) foi similar em ilhotas de ratas prenhes e não prenhes alimentadas com dieta hipoproteica, e foi maior em ilhotas de ratas prenhes do que não prenhes alimentadas com dieta normoproteica. Portanto, um curto período de dieta hipoproteica durante a prenhez foi suficiente para reduzir o conteúdo de proteínas da via da fosfatidilinositol-3-cinase e afetar a morfometria da ilhota.

Palavras-chave: via da MAP-cinase, ilhotas pancreáticas, via da PI3-cinase, prenhez, restrição de proteína, ratos.

\section{REFERENCES}

amaral me, Cunha DA, Anhe GF, Ueno M, Carneiro EM, Velloso LA, Bordin S AND Boschero AC. 2004. Participation of prolactin receptors and phosphatidylinositol 3-kinase and MAP kinase pathways in the increase in pancreatic islet mass and sensitivity to glucose during pregnancy. J Endocrinol 183: 469-476.

Amaral ME, Ueno M, CARVAlheira JB, CARneiro EM, Velloso LA, SAAd MJ AND Boschero AC. 2003. Prolactin-signal transduction in neonatal rat pancreatic islets and interaction with the insulin-signaling pathway. Horm Metab Res 35: 282-289.

Araujo EP, Amaral ME, Filiputti E, De Souza CT, Laurito Tl, Augusto VD, SaAd MJ, Boschero AC, VELlOSO LA AND CARNEIRO EM. 2004. Restoration of insulin secretion in pancreatic islets of protein-deficient rats by reduced expression of insulin receptor substrate (IRS)-1 and IRS-2. J Endocrinol 181: 25-38.

Bordin S, Amaral ME, ANHE GF, DELGHINGARO-Augusto V, CUNHA DA, NicOletTi-CARVAlHo JE AND BOSCHERO AC. 2004. Prolactin-modulated gene expression profiles in pancreatic islets from adult female rats. Mol Cell Endocrinol 220: 41-50.

BRADFORD MM. 1976. A rapid and sensitive method for the quantitation of microgram quantities of protein utilizing the principle of protein-dye binding. Anal Biochem 72: 248-254.

Brelje TC, SCHARP DW, LaCy PE, OGRen L, TALAMANTES F, RoBERTSON M, FrIESEN HG AND SORENSON RL. 1993. Effect of homologous placental lactogens, prolactins, and growth hormones on islet B-cell division and insulin secretion in rat, mouse, and human islets: implication for placental lactogen regulation of islet function during pregnancy. Endocrinology 132: 879-887.

BRELJE TC AND SORENSON RL. 1997. The physiological roles of prolactin, growth hormone and placental lactogen in the regulation of islet beta cell proliferation. In: SARVETNICK N (Ed), Pancreatic Growth and Regeneration, Basel: Karger Landes Systems, p. 1-30. 
Brelje TC, Svensson AM, Stout LE, Bhagroo NV AND SORENSON RL. 2002. An immunohistochemical approach to monitor the prolactin-induced activation of the JAK2/STAT5 pathway in pancreatic islets of Langerhans. J Histochem Cytochem 50: 365-383.

COUsin SP, Hugl SR, Myers JR MG, White MF, ReIFELMiller A AND Rhodes CJ. 1999. Stimulation of pancreatic beta-cell proliferation by growth hormone is glucose-dependent: signal transduction via janus kinase 2 (JAK2)/signal transducer and activator of transcription 5 (STAT5) with no crosstalk to insulin receptor substrate-mediated mitogenic signalling. Biochem J 344 Pt 3: 649-658.

Dickson LM, Lingohr MK, McCuaig J, Hugl SR, Snow L, KAHN BB, Myers Jr MG AND Rhodes CJ. 2001. Differential activation of protein kinase $B$ and p70(S6)K by glucose and insulin-like growth factor 1 in pancreatic beta-cells (INS-1). J Biol Chem 276: 21110-21120.

DOUMAS BT, WATSON WA AND BIGGS HG. 1971. Albumin standards and the measurement of serum albumin with bromcresol green. Clin Chim Acta 31: 87-96.

Dupouy JP, CofFIGNY H AND Magre S. 1975. Maternal and foetal corticosterone levels during late pregnancy in rats. J Endocrinol 65: 347-352.

Filiputti E, Ferreira F, SOUZA KL, Stoppiglia LF, Arantes VC, Boschero AC AND CARNEIRO EM. 2008. Impaired insulin secretion and decreased expression of the nutritionally responsive ribosomal kinase protein S6K-1 in pancreatic islets from malnourished rats. Life Sci 82: $542-548$

GAHr S, Merger M, Bollheimer LC, HAMMERSCHMiEd CG, SCHOLMERICH J AND HUGL SR. 2002. Hepatocyte growth factor stimulates proliferation of pancreatic beta-cells particularly in the presence of subphysiological glucose concentrations. J Mol Endocrinol 28: 99-110.

GalsgaARD ED, NiElsen JH AND Moldrup A. 1999. Regulation of prolactin receptor (PRLR) gene expression in insulin-producing cells. Prolactin and growth hormone activate one of the rat prlr gene promoters via STAT5a and STAT5b. J Biol Chem 274: 18686-18692.

HANNAN KM, THOMAS G AND PEARSON RB. 2003. Activation of S6K1 (p70 ribosomal protein S6 kinase 1) requires an initial calcium-dependent priming event involving formation of a high-molecular-mass signalling complex. Biochem J 370: 469-477.

HeARd CR AND Stewart RJ. 1971. Protein-calorie deficiency and disorders of the endocrine glands. Hormones 2: 4064.

Herbert DC AND CARRILlo AJ. 1982. The hypophysealadrenal axis in the protein-calorie malnourished rat. Horm Metab Res 14: 205-207.

Hogg J, Han VK, Clemmons DR AND Hill DJ. 1993. Interactions of nutrients, insulin-like growth factors (IGFs) and IGF-binding proteins in the regulation of DNA synthesis by isolated fetal rat islets of Langerhans. J Endocrinol 138: 401-412.
Hugl SR, White MF AND RHOdes CJ. 1998. Insulin-like growth factor I (IGF-I)-stimulated pancreatic beta-cell growth is glucose-dependent. Synergistic activation of insulin receptor substrate-mediated signal transduction pathways by glucose and IGF-I in INS-1 cells. J Biol Chem 273: 17771-17779.

Ihle JN, Stravapodis D, Parganas E, Thierfelder W, Feng J, Wang D And Teglund S. 1998. The roles of Jaks and Stats in cytokine signaling. Cancer J Sci Am 4 (Suppl. 1): S84-91.

Kelley GG, Zawalich KC and ZaWalich WS. 1994. Calcium and a mitochondrial signal interact to stimulate phosphoinositide hydrolysis and insulin secretion in rat islets. Endocrinology 134: 1648-1654.

KulKarni RN, WinNAY JN, DANIELS M, BRUNing JC, Flier SN, HANAHAN D AND KAHN CR. 1999. Altered function of insulin receptor substrate-1-deficient mouse islets and cultured beta-cell lines. J Clin Invest 104: R69-75.

LaWrence M, Shao C, DuAn L, McGlynn K AND CobB MH. 2008. The protein kinases ERK1/2 and their roles in pancreatic beta cells. Acta Physiol (Oxf) 192: 11-17.

LECHNER J, WeLTE T AND DOPPLER W. 1997. Mechanism of interaction between the glucocorticoid receptor and Stat5: role of DNA-binding. Immunobiology 198: 112-123.

LEVY DE AND DARNELL Jr JE. 2002. Stats: transcriptional control and biological impact. Nat Rev Mol Cell Biol 3: 651-662.

Longuet C, Broca C, Costes S, Hani EH, Bataille D AND DALLE S. 2005. Extracellularly regulated kinases 1/2 (p44/42 mitogen-activated protein kinases) phosphorylate synapsin I and regulate insulin secretion in the MIN6 beta-cell line and islets of Langerhans. Endocrinology 146: 643-654.

MAEs M, UNDERWOOd LE AND KETELSLEGERS JM. 1984. Low serum somatomedin-C in protein deficiency: relationship with changes in liver somatogenic and lactogenic binding sites. Mol Cell Endocrinol 37: 301-309.

Martin CE, CAKE MH, HARTMANN PE AND COOK IF. 1977. Relationship between foetal corticosteroids, maternal progesterone and parturition in the rat. Acta Endocrinol (Copenh) 84: 167-176.

Moldrup A, Petersen ED AND NiELSEN JH. 1993. Effects of sex and pregnancy hormones on growth hormone and prolactin receptor gene expression in insulin-producing cells. Endocrinology 133: 1165-1172.

Nadal A, Alonso-Magdalena P, Soriano S, Ropero AB AND QUESADA I. 2009. The role of oestrogens in the adaptation of islets to insulin resistance. J Physiol 587: 5031-5037.

NiSHINO Y, Michna H, HASAN SH AND SCHNEIDER MR. 1992. Involvement of the adrenal glands in the prolactin rise induced in the female rat by an antiprogestin, onapristone. J Steroid Biochem Mol Biol 41: 841-845.

PARSONS JA, BRELJE TC AND SORENSON RL. 1992. Adaptation of islets of Langerhans to pregnancy: increased islet cell proliferation and insulin secretion correlates with the onset of placental lactogen secretion. Endocrinology 130: 1459-1466. 
Pende M, Kozma SC, Jaquet M, Oorschot V, Burcelin R, LE Marchand-BRustel Y, KLUMPERMan J, ThORENS B AND ThOMAS G. 2000. Hypoinsulinaemia, glucose intolerance and diminished beta-cell size in S6K1deficient mice. Nature 408: 994-997.

Petrik J, Reusens B, Arany E, Remacle C, Coelho C, Hoet JJ AND HILL DJ. 1999. A low protein diet alters the balance of islet cell replication and apoptosis in the fetal and neonatal rat and is associated with a reduced pancreatic expression of insulin-like growth factor-II. Endocrinology 140: 4861-4873.

PiCARD F, WANATABE M, SchoONJANS K, Lydon J, O'MALLEY BW AND AUWERX J. 2002. Progesterone receptor knockout mice have an improved glucose homeostasis secondary to beta -cell proliferation. Proc Natl Acad Sci USA 99: 15644-15648.

PIMSTONE B. 1976. Endocrine function in protein-calorie malnutrition. Clin Endocrinol (Oxf) 5: 79-95.

Prewitt TE, D'ERCOLE AJ, SWITZER BR AND VAN WYK JJ. 1982. Relationship of serum immunoreactive somatomedin- $\mathrm{C}$ to dietary protein and energy in growing rats. J Nutr 112: 144-150.

Rafacho A, Roma LP, Taboga SR, Boschero AC AND BOSQUEIRO JR. 2007. Dexamethasone-induced insulin resistance is associated with increased connexin 36 mRNA and protein expression in pancreatic rat islets. Can J Physiol Pharmacol 85: 536-545.

RAO YP, BuCKLEY DJ AND BUCKLEY AR. 1995. Rapid activation of mitogen-activated protein kinase and p21 ras by prolactin and interleukin 2 in rat $\mathrm{Nb} 2$ node lymphoma cells. Cell Growth Differ 6: 1235-1244.

SCHARFMANN R AND CZERNICHOW P. 1996. Differentiation and growth of pancreatic beta cells. Diabetes Metab 22: 223-228.

SOKAL RR AND RoHLF FJ. 1995. Assumptions of analysis of variance. In: SOKAL RR and ROHLF FJ (Eds), Biometry: the principles and practice of statistics in biological research: WH Freeman \& Co, p. 392-450.
SORENSON RL AND BRELJE TC. 1997. Adaptation of islets of Langerhans to pregnancy: beta-cell growth, enhanced insulin secretion and the role of lactogenic hormones. Horm Metab Res 29: 301-307.

Stocklin E, Wissler M, GOUILleuX F AND GRONER B. 1996. Functional interactions between Stat5 and the glucocorticoid receptor. Nature 383: 726-728.

SwenNe I, Borg LA, CRACE CJ AND SCHNEll LANDSTROM A. 1992. Persistent reduction of pancreatic beta-cell mass after a limited period of protein-energy malnutrition in the young rat. Diabetologia 35: 939-945.

Tuttle RL, Gill NS, Pugh W, LeE JP, Koeberlein B, Furth EE, Polonsky KS, NaJi A And Birnbaum MJ. 2001. Regulation of pancreatic beta-cell growth and survival by the serine/threonine protein kinase Akt1/PKBalpha. Nat Med 7: 1133-1137.

WeInHaUs AJ, BHAgroo NV, BRELJE TC AND SORENSON RL. 2000. Dexamethasone counteracts the effect of prolactin on islet function: implications for islet regulation in late pregnancy. Endocrinology 141: 1384-1393.

Weinkove C, Weinkove E, Timme A and Pimstone B. 1977. Pancreatic islets of malnourished rats: quantitative histologic and electron microscopic findings. Arch Pathol Lab Med 101: 266-269.

WITHERS DJ ET AL. 1998. Disruption of IRS-2 causes type 2 diabetes in mice. Nature 391: 900-904.

WYSZOMIERSKI SL, YeH J AND ROSEN JM. 1999. Glucocorticoid receptor/signal transducer and activator of transcription 5 (STAT5) interactions enhance STAT5 activation by prolonging STAT5 DNA binding and tyrosine phosphorylation. Mol Endocrinol 13: 330-343.

YAMAUCHI T ET AL. 1998. Growth hormone and prolactin stimulate tyrosine phosphorylation of insulin receptor substrate-1, -2, and -3, their association with p85 phosphatidylinositol 3-kinase (PI3-kinase), and concomitantly PI3-kinase activation via JAK2 kinase. J Biol Chem 273: 15719-15726. 